\title{
APPRAISAL OF PROPERTY OF LOCAL SELF- GOVERNMENT BODIES: A ROLE IN THE EFFECTIVENESS OF PROPERTY PRIVATIZATION AS A SOURCE OF INCREASING REVENUES OF LOCAL BUDGETS
}

\section{Liliia P. Tymoshchyk}

Scientific Secretary, Scientific Research Centre for Forensic Examination on Intellectual Property of the Ministry of Justice of Ukraine, Kyiv, Ukraine

\begin{abstract}
The correct appraisal of state property, which depends on the professionalism of property evaluation institutions, ensures the fiscal efficiency of privatization. The lack of research on the fiscal effects of property appraisal requires the study of the effectiveness of the appraisal procedure. The article deals with the issue of appraisal activity of municipal property in the context of property privatization and fiscal efficiency. The main purpose of the study was to determine the role of appraisal of property of local self-governments in the effectiveness of property privatization. The statistical analysis of property appraisal and privatization indicators revealed the peculiarities of property appraisal and its fiscal efficiency. Mechanisms for ensuring proper appraisal of municipal property in developed and developing countries are identified. The main conceptual differences of property appraisal mechanisms are revealed: market approach in developed countries through the mechanism of public offering of shares; formation of competition through a transparent mechanism of electronic auctions in developing countries. The concept of municipal asset management provides the preconditions for independent appraisal institutions and simplifies appraisal procedures, and finally - privatization procedure. The article established that a correct appraisal of municipal property provides short-term fiscal effects. The study provides an opportunity to implement an appraisal mechanism based on a market approach in developing countries. The influence of the municipal asset appraisal on budget volumes through current financing and long-term receipt of tax payments is proved.
\end{abstract}

Keywords: Municipal property appraisal, Privatization, Fiscal efficiency, Effects of property valuation, Municipal asset appraisal, State property 
Cite this Article: Liliia P. Tymoshchyk, Appraisal of Property of Local SelfGovernment Bodies: A Role in the Effectiveness of Property Privatization as a Source of Increasing Revenues of Local Budgets, International Journal of Management, 11 (6), 2020, pp. 560-576.

http://iaeme.com/Home/issue/IJM?Volume=11\&Issue $=6$

\section{INTRODUCTION}

State property privatization in the transition to a market economy necessitates municipal property appraisal. Incompetent appraisal of state property, and, as a consequence, the loss of revenues of the state budget in case of privatization, may be the cause of the unformed institution of appraisers of movable and immovable property. "Regulatory infrastructure", which includes the infrastructure of the institute of appraisers, is an important prerequisite for the effective privatization of state property. This problem has existed in Ukraine for a long time. The adoption of the Law on Privatization launched a system of mass appraisal of state property in Ukraine. The opposite problem of incompetent appraisal due to the lack of an institute of appraisers, which usually leads to low sales costs, is the maximization of sales prices by local authorities for political purposes [1]. Determinants and factors of property appraisal in countries with economies in transition are much more complex than those of developed countries, complemented by the complexity of privatization procedures. The determinants of appraisal, accounting and management of state property are institutional and non-institutional factors [2].

Additional determinants of correct appraisal are: functional classification of state property; consistent accounting and inventory; accounting for income and expenditure of state property; recurrent evaluation of financial indicators of property subject to appraisal; formation of criteria for property appraisal when deciding on privatization [3].

Pricing and appraisal of assets to be privatized is a critical issue of privatization, as it determines the impact on income distribution in the country [4]. Methods of appraising state property depend on the political and macroeconomic conditions of the country [2]. Countries with an underdeveloped capital market cannot ensure the use of a market-based approach to property appraisal through public offering [4].

Empirical research has virtually no information on the economic effects of municipal property appraisal, and partially mentions the issues and importance of property appraisal. As in developed countries property appraisal was large-scale and mass, the issue of state property appraisal has not become widespread and discussed.

Given a number of problems in the field of municipal property appraisal, the purpose of the article is to determine the role of appraisal of property of local self-governments in the effectiveness of property privatization.

The main objectives of the study are:

1. Review of the practice of property appraisal in the privatization of developed countries (on the example of the EU).

2. Analyse the features of the appraisal of property subject to privatization in Ukraine.

3. Identify the features of privatization (procedures and stages) and the mechanism of property appraisal in Ukraine.

4. Determine the economic effects of the state property appraisal during privatization in Ukraine.

The main hypotheses of the study are:

Hypothesis 1. Appraisal of property of territorial communities subject to privatization provides a higher level of revenues to local budgets in the short term. 
Appraisal of Property of Local Self-Government Bodies: a Role in the Effectiveness of Property Privatization as a Source of Increasing Revenues of Local Budgets

Hypothesis 2. Appraisal of property of territorial communities subject to privatization provides attraction of additional receipts from tax payments in the long run.

The study will provide an opportunity to use the results of the analysis of the economic effects of property appraisal to calculate the planned revenues to local budgets during the privatization of municipal property. Thus, this article is an original study of how the state property appraisal determines the level of revenues to local budgets.

\section{LITERATURE REVIEW}

Scientific literature on the effectiveness of privatization of state property and its economic effects was mainly published in the 1990's, during the period of mass privatization and property appraisal in developed countries. Instead, since 2000, research has focused on narrower subjects and empirical assessments of privatization $[3,5]$. The need for a combination of balance and management methods of appraisal of state property to be privatized was proved [3]. The concept of New Public Governance changed approaches to privatization, regulatory and institutional factors have become important conditions for the effectiveness of privatization [6]. In countries with economies in transition, privatization reforms are becoming increasingly important as the level of public administration of privatization procedures increases.

In recent years, the concept of municipal asset management has been developed [7]. There are discussions about the effectiveness of partial privatization, which provides social orientation even in the long run [8]. New forms of privatization with a social dimension - "social impact bonds" - are explored [9]. SIB operates on a "pay for success" principle, in which a private corrections provider is only paid if it delivers on measurable outcomes deemed to be socially beneficial (e.g., reduced recidivism). The classic typical SIB involves numerous parties: private investors to finance the correctional service, a private firm to deliver the service, a private firm to evaluate the program, and a government authority to reimburse private investors if the program meets the designated benchmarks [9].

The optimal model of privatization (partial and/or full) depends on the state of competition in the market and the type of market [8]. Accordingly, the level of development of market mechanisms, the level of competitiveness of markets in transition economies and developed economies in general determine the efficiency of the appraisal market (number of firms-subjects of state property appraisal), market type (oligopoly, duopoly, monopoly). At the municipal level, the effect of a high level of privatization is expressed in a lower level of satisfaction with the quality of public services, which stems from the ideological orientation of local authorities [10]. Accordingly, there are differences in the fiscal effects of privatization at the national and municipal levels, and therefore local appraisal of property subject to privatization may also experience a similar impact, a certain level of subjectivity.

At the same time, there is no quantitative assessment of the role of municipal property appraisal in the literature, while privatization and property appraisal are intensifying in countries with economies in transition, in particular in Ukraine in 2018-2020.

As privatization intensified in developing countries (Africa and South Asia) after 2000, recent studies identify types of privatization and allow identifying approaches to state asset appraisal [4, 11]. Privatization in South Asia (India, Pakistan, Afghanistan, Bangladesh, Nepal and Sri Lanka) occurred through partial privatization, strategic sales until 2000, and the sale of shares (including secondary) in 2000-2008 in the infrastructure, energy and financial sectors, sectors of production and services [4]. Thus, the appraisal process based on a market approach. The market approach to appraisal in general is marked by efficiency, ensuring the growth of profitability of companies after privatization, the development of competition. The regulatory framework of South Asian countries significantly affects the efficiency of privatization processes [7]. Additional factors for the effectiveness of privatization are a favourable 
macroeconomic environment and independent institutions, including independent appraisers [4]. As a result, "privatization has transformed the nature of state control to emphasize regulatory power" [11].

Asset appraisal during privatization by discounting the amount of profit derived from operations with the assets means substituting the flow of income of the discounted value of asset capital with the value of assets in the portfolio (i.e., the sale price of the property). The initial asset price determines the distribution of income between taxpayers and new owners of state property in the future [4]. In addition, new flows of tax payments are formed after privatization. If the efficiency of privatized property increases, tax payments will increase compared to the period of public administration (Figure 1).

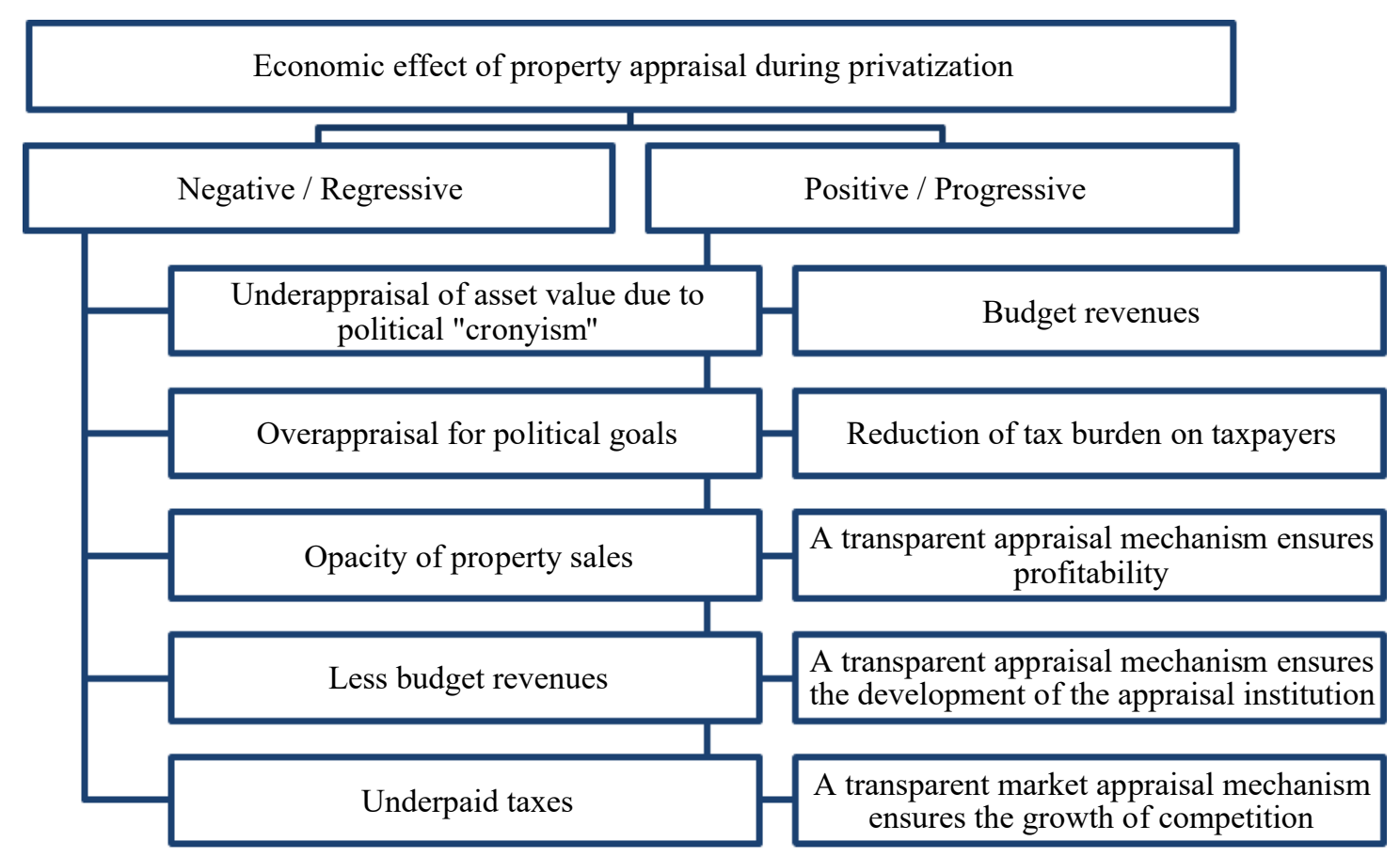

Figure 1 Generalization of the effects of property appraisal in the privatization process

Source: developed on the basis of [4]

The non-transparent mechanism of state property appraisal is due to corruption, and involves the dissemination of insider information among certain groups of individuals. An opaque appraisal mechanism may also affect future tax payments on proceeds derived from privatized property. Focusing on the short-term effects of property privatization offsets future potential benefits (including innovation benefits at the local level) [12]. In addition, the privatization of state-owned facilities has a negative impact on the control of corruption in the country in the context of low accountability and underdeveloped independent institutions [13].

The non-transparent appraisal mechanism is usually the case for the countries with economies in transition, with underdeveloped competitive environment [4]. The price of state property, which is formed in a developed competitive business environment, provides a higher level of fiscal efficiency [14]. The effectiveness of pricing depends on the country and the preconditions available in the country [15]. Limited access to world capital markets, characteristic of transition economies, determines the level of competition, and affects the establishment of property value [16]. Net fiscal revenues from privatized property may be about $1 \%$ of GDP [4]. The experience of the Czech Republic and Russia is an example of a non- 
transparent mechanism for the transfer of state assets at zero or nominal price. The lack of open bidding, which is a key aspect of ensuring a correct asset appraisal based on a market approach, has led to the transfer of ownership to a concentrated limited number of economic agents in these countries [11]. At the same time, the desire of the authorities to maximize tax revenues through privatization may lead to negative side effects of property appraisal in the form of increased competition from foreign buyers [4].

In general, state assets are often under appraised for a variety of reasons: to make them more attractive to the market; unprofitable state-owned enterprises; short-term budget balancing requirements prevailed over the requirements of forming a long-term portfolio of state assets; ideological goals of privatization in the context of ensuring the redistribution of state property in the private sector. An example is the experience of the United Kingdom, where there was an increase in private capital in favour of particular legal entities in 1970-2010 [11]. Thus, the underappraisal of state property leads to growing inequality in the country. An effective institution of property appraisal is a mechanism to protect against the redistribution of state property in favour of particular economic agents. Properly appraised state assets have a positive impact on the fiscal balance, reflecting future profits from the company (flows of tax payments).

\section{METHODS AND MATERIALS}

The study is based on the concept of municipal asset management, which includes methodological management and balance methods of municipal property appraisal, market conditions for pricing of state and municipal property $[3,7,17,18]$.

\subsection{Sample}

This study analyses EU data available on the Privatization Barometer (PB) website. PB is the official provider of private data to the Organization for Economic Co-operation and Development (OECD) and the World Bank. The PB website shows all privatization transactions from 1977 to 2013 in Europe.

Indicators of privatization of Ukraine are available on the website of the State Property Fund for 2018-2020, which resulted in the limitation of the study in terms of comparing the practice of privatization of Ukraine and the EU.

\subsection{Variables}

The author selected the following main indicators for determining the role of property appraisal: the appraisal value of appraised property in Ukraine for 2018-2020; number of property to be appraised and privatized; the ratio of the appraisal value to the amount of revenues derived from privatization of property determined by the budget (2020); the share of the number of appraisal property to a certain number of privatization property; volumes of revenues to local budgets of Ukraine for 2019. The study and generalization of selected indicators served as a basis for drawing conclusions on the subject of research.

The main variables that characterized the privatization reforms of the EU countries were: (i) DEALS refers to the number of privatization transactions (both partial and total) conducted in a country by year; and (ii) PROCEEDS represents the total revenue (in current US \$) from privatization deals that occurred in a country by year, as a proportion of GDP (in current US\$). The first variable (DEALS) represents the progress of privatization, whereas the PROCEEDS variable represents the economic impact of such reforms [6]. Considering the number of transactions underestimates the economic effect of privatizations, while considering only the revenue from such reforms overestimates the impact of privatizations when only a few large SOEs are involved [6]. 


\subsection{Methods}

The study is based on a statistical analysis of data on the volume of privatization in the EU for the period 1979-2013 from the Privatization Barometer database. Statistical analysis of data on privatization in Ukraine was conducted on the basis of reports of the State Property Fund for 2018-2020 and analysis of the legal framework for regulating the mechanism of property appraisal in Ukraine according to the State Property Fund, the Verkhovna Rada of Ukraine.

\section{RESULTS}

\subsection{Privatization processes in EU countries}

In the EU, state property was privatized in 1980-1990 to ensure the economic efficiency of enterprises by increasing productivity and income, reducing government intervention, and promoting increased competition in monopolized industries. The peak of privatization in the EU countries occurred in 1997-2000 (Figure 2), then in 2004-2008 (during the period of economic growth), and 2012-2013.

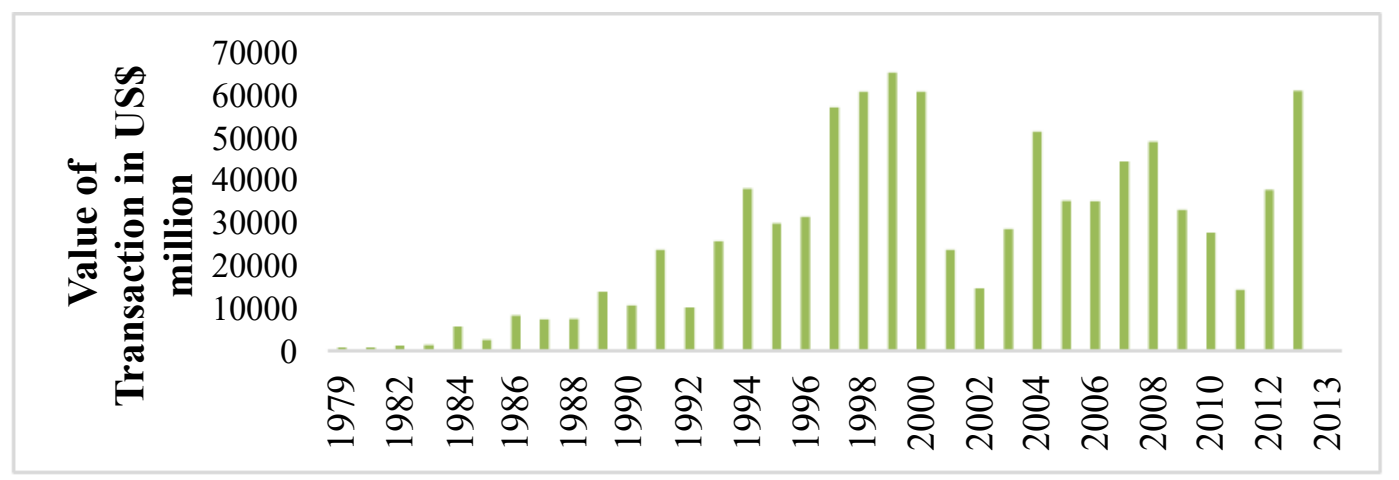

Figure 2 Dynamics of volumes of transactions from privatization in the EU countries for 1979-2013

Source: based on the [19]

The ranking of countries by the volume of transactions from privatization in the EU for 1979-2013 (Figure 3) shows the revenues of state budgets derived from privatization for 19792013.

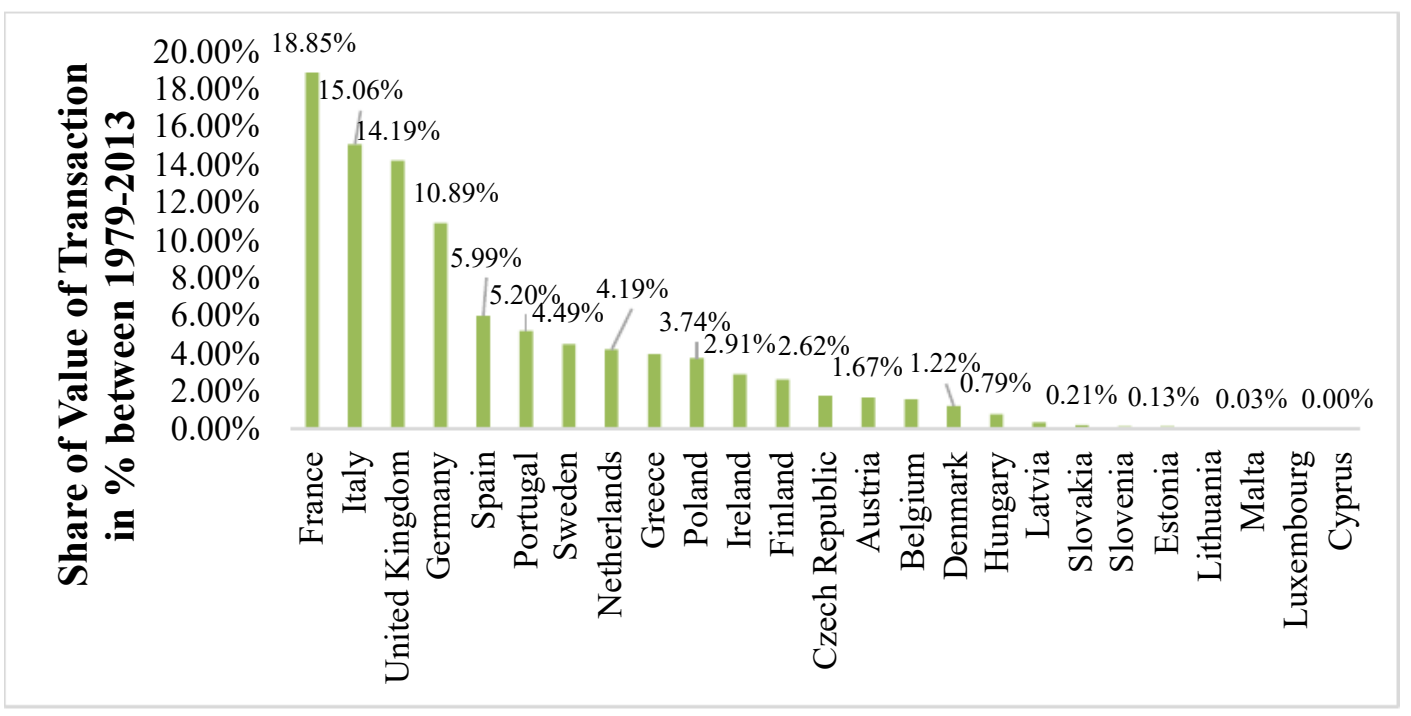

Figure 3 Ranking of countries by volumes of transactions from privatization in the EU for 1979-2013, $\%$ 
Source: based on the [19]

The most "privatized" sectors of the economy (Table 1) were the financial sector (\$227,427.7 million in 1979-2013), services (\$213,869.1 million in 1979-2013), and telecommunications $(\$ 188,314.1$ million for 1979-2013), production $(\$ 111,241.5$ million for 1979-2013), transport ( $\$ 79,452.8$ million for 1979-2013). The average share of privatization in the sector was $36.04 \%$. The largest shares of enterprise privatization were in the agricultural sector $(57.9 \%)$, public administration $(56.15 \%)$, trade $(53.31 \%)$, extraction of natural resources $(52.49 \%)$, service sector $(40.40 \%)$, and production $(41.03 \%)$. The largest number of enterprises has been privatized in manufacturing, the financial sector, the service sector, transport, and telecommunications.

Table 1 Volumes of privatization transactions in the EU countries by economic sectors for 1979-2013, $\$$ million and \%

\begin{tabular}{|c|c|c|c|}
\hline Industry & $\begin{array}{l}\text { Value of Transaction in } \\
\$ \text { million, 1979-2013 }\end{array}$ & $\begin{array}{c}\text { \% for Sale, } \\
\text { Average 1979- } \\
2013\end{array}$ & $\begin{array}{l}\text { Number of Companies that } \\
\text { was privatized } 1979-2013\end{array}$ \\
\hline $\begin{array}{l}\text { Agriculture } \\
\text { Industry }\end{array}$ & 483.036474 & 57.90 & 28 \\
\hline Construction & $5,245.449$ & 30.93 & 47 \\
\hline $\begin{array}{l}\text { Finance \& Real } \\
\text { Estate Industry }\end{array}$ & $227,427.6597$ & 36.39 & 441 \\
\hline Manufacturing & $111,241.4963$ & 41.03 & 799 \\
\hline $\begin{array}{c}\text { Natural } \\
\text { Resources }\end{array}$ & $6,189.0873$ & 52.49 & 33 \\
\hline $\begin{array}{l}\text { Petroleum } \\
\text { Industry }\end{array}$ & $55,009.542$ & 21.16 & 87 \\
\hline $\begin{array}{c}\text { Public } \\
\text { Administration }\end{array}$ & 799.352 & 56.15 & 20 \\
\hline $\begin{array}{l}\text { Services } \\
\text { Industry }\end{array}$ & $21,500.66105$ & 40.40 & 214 \\
\hline $\begin{array}{l}\text { Telecommunicat } \\
\text { ions }\end{array}$ & $188,314.149$ & 19.19 & 157 \\
\hline Trade Industry & $5,949.368$ & 53.31 & 79 \\
\hline $\begin{array}{l}\text { Transportation } \\
\text { Industry }\end{array}$ & $79,452.78241$ & 37.14 & 268 \\
\hline Utilities & $213,869.1457$ & 32.38 & 333 \\
\hline Total & $915,481.7289$ & 36.04 & 2,506 \\
\hline
\end{tabular}

Source: based on the [19]

Strategic privatization in developed countries provided for the creation of institutional, legal and financial preconditions. The synergetic effect of these preconditions ensured the development of competition and the implementation of a market approach to property appraisal. In countries with economies in transition (transition to market conditions and the formation of a competitive environment), the processes of privatization and appraisal of property, as one of the stages of privatization, differ due to the level of governance efficiency. As the concept of public governance is still not widespread in transition economies, private property appraisal institutions are not enough effective. At the same time, the efficiency of public governance affects the efficiency of privatization, "governance infrastructures are key determinants of privatization reforms, but the effect depends on economic development" [6]. The cases of privatization of the Czech Republic, Estonia, Latvia, Lithuania, Slovakia, Slovenia and Poland 
differ in a number of features in the appraisal procedure. In particular, "there is a fundamental difficulty in determining the value of state-owned companies" [20]. In a market economy, the main instrument of property appraisal is the securities exchange. The lack of established capital markets in transition economies and, at the same time, the need for privatization as a condition for transition to the market exacerbate the problem of correct property appraisal. In fact, the market is not able to appraise property using market mechanism. Accordingly, property appraisal is based on a transparent legal appraisal mechanism. Under such conditions, privatization does not occur according to market estimates and the market value of state property, but chaotically, depending on macroeconomic and political factors (Table 2).

Table 2 Volumes of privatization transactions in the EU countries in terms of privatization methods for 1979-2013, \$ million and \%

\begin{tabular}{|c|c|c|c|}
\hline $\begin{array}{l}\text { Method of } \\
\text { Sale }\end{array}$ & $\begin{array}{c}\text { Transaction 1977-2013, } \\
\text { \$ million }\end{array}$ & $\begin{array}{c}\text { Share of privatization } \\
\text { method, } \%\end{array}$ & $\begin{array}{c}\text { Approach to property } \\
\text { appraisal }\end{array}$ \\
\hline \multicolumn{4}{|c|}{ Austria } \\
\hline $\mathrm{PO}$ & $9,340.671$ & $49 \%$ & Market \\
\hline PS & $9,558.5495$ & $51 \%$ & Non-market \\
\hline Total & $18,899.2205$ & $100 \%$ & - \\
\hline \multicolumn{4}{|c|}{ Belgium } \\
\hline $\mathrm{PO}$ & $3,450.19$ & $23 \%$ & Market \\
\hline PS & $11,361.946$ & $77 \%$ & Non-market \\
\hline Other & 13.4 & $0 \%$ & - \\
\hline Total & $14,825.536$ & $100 \%$ & - \\
\hline \multicolumn{4}{|c|}{ Czech Republic } \\
\hline $\mathrm{PO}$ & 564.67 & $3 \%$ & Market \\
\hline PS & $19,177.802$ & $97 \%$ & Non-market \\
\hline Total & $19,742.472$ & $100 \%$ & - \\
\hline \multicolumn{4}{|c|}{ Estonia } \\
\hline $\mathrm{PO}$ & 540.698 & $41 \%$ & Market \\
\hline PS & 773.399 & $59 \%$ & Non-market \\
\hline Total & $1,314.097$ & $100 \%$ & - \\
\hline \multicolumn{4}{|c|}{ France } \\
\hline $\mathrm{PO}$ & $136,521.689$ & $61 \%$ & Market \\
\hline PS & $86,784.258$ & $39 \%$ & Non-market \\
\hline Total & $223,305.947$ & $100 \%$ & - \\
\hline \multicolumn{4}{|c|}{ Germany } \\
\hline $\mathrm{PO}$ & $66,245.33$ & $46 \%$ & Market \\
\hline PS & $77,867.719$ & $54 \%$ & Non-market \\
\hline Total & $144,113.049$ & $100 \%$ & - \\
\hline \multicolumn{4}{|c|}{ Hungary } \\
\hline $\mathrm{PO}$ & $4,411.72$ & $27 \%$ & Market \\
\hline PS & $11,838.7911$ & $73 \%$ & Non-market \\
\hline Total & $16,250.5111$ & $100 \%$ & - \\
\hline \multicolumn{4}{|c|}{ Italy } \\
\hline $\mathrm{PO}$ & $118,182.8434$ & $66 \%$ & Market \\
\hline PS & $60,290.7849$ & $34 \%$ & Non-market \\
\hline Total & $178,473.6283$ & $100 \%$ & - \\
\hline
\end{tabular}


Appraisal of Property of Local Self-Government Bodies: a Role in the Effectiveness of Property Privatization as a Source of Increasing Revenues of Local Budgets

\begin{tabular}{|c|c|c|c|}
\hline $\begin{array}{l}\text { Method of } \\
\text { Sale }\end{array}$ & $\begin{array}{c}\text { Transaction 1977-2013, } \\
\text { \$ million }\end{array}$ & $\begin{array}{c}\text { Share of privatization } \\
\text { method, } \%\end{array}$ & $\begin{array}{c}\text { Approach to property } \\
\text { appraisal }\end{array}$ \\
\hline \multicolumn{4}{|c|}{ Latvia } \\
\hline $\mathrm{PO}$ & $2,094.18$ & $62 \%$ & Market \\
\hline PS & $1,306.784$ & $38 \%$ & Non-market \\
\hline Total & $3,400.964$ & $100 \%$ & - \\
\hline \multicolumn{4}{|c|}{ Lithuania } \\
\hline $\mathrm{PO}$ & 181.7 & $6 \%$ & Market \\
\hline PS & $2,921.538$ & $94 \%$ & Non-market \\
\hline Total & $3,103.238$ & $100 \%$ & - \\
\hline \multicolumn{4}{|c|}{ Poland } \\
\hline $\mathrm{PO}$ & $29,901.1043$ & $58 \%$ & Market \\
\hline PS & $21,685.12914$ & $42 \%$ & Non-market \\
\hline Total & $51,586.23344$ & $100 \%$ & - \\
\hline \multicolumn{4}{|c|}{ Slovakia } \\
\hline PS & $8,220.1421$ & $100 \%$ & Non-market \\
\hline \multicolumn{4}{|c|}{ Slovenia } \\
\hline $\mathrm{PO}$ & 596.7 & $19 \%$ & Market \\
\hline PS & $2,536.78$ & $81 \%$ & Non-market \\
\hline Total & $3,133.48$ & $100 \%$ & - \\
\hline \multicolumn{4}{|c|}{ Spain } \\
\hline $\mathrm{PO}$ & $38,184.618$ & $63 \%$ & Market \\
\hline PS & $22,816.418$ & $37 \%$ & Non-market \\
\hline Total & $61,001.036$ & $100 \%$ & - \\
\hline \multicolumn{4}{|c|}{ Sweden } \\
\hline $\mathrm{PO}$ & $27,231.913$ & $47 \%$ & Market \\
\hline PS & $31,283.3125$ & $53 \%$ & Non-market \\
\hline Total & $58,515.2255$ & $100 \%$ & - \\
\hline \multicolumn{4}{|c|}{ United Kingdom } \\
\hline $\mathrm{PO}$ & $117,120.705$ & $67 \%$ & Market \\
\hline PS & $56,499.095$ & $33 \%$ & Non-market \\
\hline Total & $173,619.8$ & $100 \%$ & - \\
\hline
\end{tabular}

Source: based on the [19]

In Austria, Estonia, France, Germany, Italy, Latvia, Poland, Spain, Sweden, and the United Kingdom, market mechanisms of property appraisal through public offerings and the stock market prevailed (Table 2). In Belgium, the Czech Republic, Hungary, Lithuania, and Slovenia, non-market mechanisms prevailed: voucher privatization and the sale of shares to employees led to significant underappraisal. This has led to chaos in privatization procedures and approaches to property appraisal in EU countries. As a result, it has significantly affected the fiscal effectiveness of privatization reforms. Transition economies differ significantly in the mechanisms of state property appraisal during privatization. Spontaneous privatization, when managers or employees transfer assets into new private companies, took place primarily in Hungary and Poland, while in Czechoslovakia and East Germany, the privatization process was more under the control of the government and took place through open auctions [20]. Instead, in developed EU countries, property appraisal was conducted on the basis of a thorough study of the value of state assets with the help of consulting agencies and investment banks. 
Some EU countries (Czechoslovakia, Poland, Russia and Bulgaria) carried out mass property privatization on the basis of state privatization programs "by offering the enterprises to the population at little to no cost" [20]. Mass privatization took place through the sale of vouchers in the Czech Republic. The Czech privatization policy foresaw the development of the capital market through voucher trading and the development of the stock market. Another form is the sale of companies to foreign investors, which was mainly the case for sectors with a high level of profitability. Less profitable companies were privatized by domestic economic agents with the involvement of loans.

The experience of EU countries in general shows that there are three types of privatization that have affected property valuation and fiscal efficiency: 1) mass voucher privatization; 2) sale of property through shares to employees of enterprises; 3 ) sale of property to domestic and foreign investors. Accordingly, the procedure and approaches to state property appraisal were characterized by regional differences. For example, in Poland, the privatization policy was gradual, which affected the fiscal efficiency of all procedures. As a result of the liquidation of Polish enterprises, state property was under appraised in case of sales or leased at reduced prices. At the same time, the possibility of selling shares of state-owned enterprises on the stock market ensured greater fiscal efficiency of privatization procedures. At the same time, the liquidation of 1,600 Polish enterprises in the privatization process testifies to the massive problem of property underappraisal during the transition to a market economy.

In Hungary, on the other hand, privatization took place through the transformation of private enterprises into joint stock companies, and the assets of enterprises were sold legally or illegally. Accordingly, the price of state property was significantly reduced. This led to public protest and the creation of the Hungarian National Asset Management [20] as an institution to manage privatization procedures.

In general, the experience of privatization of EU countries shows the importance of establishing a national regulator that will ensure the legality of procedures and reduce the risks of underappraisal of state property. The lack of such regulators in transition economies has affected the success of privatization: mass privatization has led to an underappraisal of property and led to mass protests against illegal privatization procedures. The regulators, the legal environment for property valuation, and socially oriented privatizations are emerging in response to public protests.

\subsection{Features of privatization and the mechanism of appraisal of property subject to privatization in Ukraine}

From the beginning of August 2018, the State Property Fund of Ukraine began to publish weekly information on the number, appraisal value of state and communal property by region, type of property appraised, main characteristics of the property (year of starting operation, engineering and physical characteristics, analysis of the most effective use). The database of appraisal reports allows you to group property appraises by type, number and total appraisal value. In fact, a mass appraisal of state and communal property with the application of the practice of developed countries has been going on in Ukraine since the end of 2018. This provides increased level of transparency, openness and efficiency of privatization, the formation of competition in sales based on a market approach. An additional factor in the effectiveness of the appraisal of property subject to privatization was the development of legislation governing the appraisal institution and the activities of entities engaged in appraisal.

Evaluation of information on the appraised value of property in Ukraine for the period of 13.08.2018 - 04.06.2020 confirms the mass appraisal activity of state property of Ukraine (Table 3). The average number of appraised properties is 13,505 , i.e. there is an ongoing mass inventory of state and municipal property. Residential property, land plots and industrial 
Appraisal of Property of Local Self-Government Bodies: a Role in the Effectiveness of Property Privatization as a Source of Increasing Revenues of Local Budgets

(warehouse) property are being appraised the fastest. The volumes of state property appraisal significantly exceed the privatization volumes.

Table 3 Information on the appraised value of property in Ukraine as of 29.05.2020-04.06.2020 [21]

\begin{tabular}{|c|c|c|c|c|}
\hline $\begin{array}{c}\text { Type of } \\
\text { appraised } \\
\text { property }\end{array}$ & $\begin{array}{c}\text { Appraised value } \\
\text { of property, } \\
\text { UAH }\end{array}$ & $\begin{array}{c}\text { Number } \\
\text { of } \\
\text { appraised } \\
\text { property } \\
\text { items }\end{array}$ & $\begin{array}{c}\text { Ratio of appraised } \\
\text { value in the amount } \\
\text { of revenues from } \\
\text { property } \\
\text { privatization } \\
\text { determined by the } \\
\text { budget (2020) }\end{array}$ & $\begin{array}{c}\text { Share of the } \\
\text { number of } \\
\text { appraised } \\
\text { properties to a } \\
\text { certain number of } \\
\text { privatized } \\
\text { property }\end{array}$ \\
\hline $\begin{array}{c}\text { Administrative } \\
\text { property }\end{array}$ & $119,342,369.15$ & 134 & 0.24 & $0.01 \%$ \\
\hline $\begin{array}{c}\text { Industrial } \\
\text { (warehouse) } \\
\text { property }\end{array}$ & $235,068,630.59$ & 641 & 0.47 & $0.05 \%$ \\
\hline $\begin{array}{c}\text { Commercial } \\
\text { property }\end{array}$ & $67,684,800.65$ & 113 & 0.14 & $0.01 \%$ \\
\hline Residential \\
property & $2,748,128,666.26$ & 6,496 & 5.50 & $0.55 \%$ \\
\hline Land plot & $532,230,617.95$ & 6,121 & 1.06 & $0.52 \%$ \\
\hline Total & $3,702,455,084.60$ & 13,505 & 7.40 & $1.15 \%$ \\
\hline
\end{tabular}

In Ukraine, according to the information of management entities and the results of the inventory of state property in the Register [22], the statistics as of January 1, 2020 is as follows:

- 20.2 thousand legal entities that operate on the basis of state ownership only and belong to the sphere of management of the respective agents of management;

- 439 business organizations with corporate rights of the state;

- more than 1 million items of state property, including: 560.0 thousand real estate of state enterprises, institutions, organizations; 585.0 thousand items of state property, which were not included in the authorized capital of companies in the process of corporatization, but remained on their balance sheet; 26.2 thousand items of state property, which were not included in the authorized capital of companies in the process of privatization, but remained on their balance sheet [22].

Agents of management provided information on real estate of state-owned enterprises, institutions and organizations in relation to 9.2 thousand legal entities (companies accounting for the assets), and reported that 10.7 thousand legal entities do not account for real estate on their balance sheets. The lack of accounting for state property directly affects the quality, speed and efficiency of appraisal, especially in the context of the new 2020 solvency crisis. The new crisis is characterized by an increased risk of non-receipt of tax payments by local budgets from enterprises. This may necessitate the sale of municipal property. Lack of accounting for property and the need for immediate receipt of revenues to the budget through its sale, financing of current expenditures can have a negative impact on privatization and reduce value.

During 2019, 394 properties subject to privatization changed their state form of ownership, while in 2018 - 249 items. In 2019, UAH 546.785 million was received from the privatization of state property. The state budget received UAH 549.471 million (taking into account the balance as of 01.01.2019 in the amount of UAH 6.7 million). In 2018, UAH 268.65 million was transferred from the privatization of state property to the state budget. Over all the years, more than UAH 68 billion has been received from the privatization of state property. (State Property Fund of Ukraine, 2020). 
In 2020, 25 large-scale properties are subject to privatization, which are being prepared for privatization by the staff of the State Property Fund. The lists of small properties subject to privatization in 2020, as of March 31, 2020, contained 1,010 small property items, of which: 839 properties are subject to sale at electronic auctions; 111 properties are subject to privatization in accordance with the requirements of Articles 16, 18 of the Law on Privatization; 60 properties are in the process of determining the way of privatization. Thus, the privatization of more properties is based on a market approach, which, according to current legislation, provides for the establishment of a market price of properties in an electronic auction.

In order to prepare property subject to privatization for sale during the first quarter of 2020 , the relevant orders of the privatization bodies decided to privatize 244 small properties and established 201 auction commissions for their sale. In accordance with the requirements of the Law on Privatization, small properties subject to privatization shall be sold at electronic auctions only using an electronic trading system through operators of electronic platforms, which have been authorized in accordance with the procedure established by the Cabinet of Ministers of Ukraine. As of March 31, 2020, the Fund has concluded agreements on conducting electronic auctions for the sale of small privatized properties with 41 operators of electronic platforms, authorized by ProZorro.Sales. During the first quarter of 2020, 226 small privatized properties were put up for electronic auctions, of which 92 were sold for a total amount of UAH 353,816.92 thousand (starting price UAH 254,893.86 thousand), the increase in the sale price was $138.81 \%$ (Table 4). Besides, in accordance with Articles 16 and 18 of the Law on Privatization, 2 properties worth UAH 1,232.47 thousand were sold by state privatization bodies through redemption. In total, UAH 201,431.6 thousand was transferred to the state budget from the privatization of small properties in accordance with the concluded agreements as of March 31, 2020 [23].

Table 4 Sale of small privatized properties at electronic auctions for the $1^{\text {st }}$ quarter of 2020 in Ukraine

\begin{tabular}{|c|c|c|c|c|}
\hline Auction type & $\begin{array}{c}\text { Number of } \\
\text { property } \\
\text { items }\end{array}$ & $\begin{array}{c}\text { Sale price, } \\
\text { UAH } \\
\text { thousand }\end{array}$ & $\begin{array}{c}\text { Starting } \\
\text { price, UAH } \\
\text { thousand }\end{array}$ & $\begin{array}{c}\text { Difference } \\
+/-\end{array}$ \\
\hline $\begin{array}{c}\text { by the method of step-by-step } \\
\text { reduction of the starting price and } \\
\text { subsequent bidding }\end{array}$ & 28 & $18,021.93$ & $35,869.47$ & $-49.75 \%$ \\
\hline $\begin{array}{c}\text { with conditions (without } \\
\text { conditions) }\end{array}$ & 26 & $312,641.64$ & $200,626.12$ & $+55.93 \%$ \\
\hline $\begin{array}{c}\text { with a reduction of the starting } \\
\text { price by 50\% }\end{array}$ & 15 & $15,511.35$ & $11,114.03$ & $+39.56 \%$ \\
\hline $\begin{array}{c}\text { through redemption by the buyer, } \\
\text { who is the only one to apply for } \\
\text { participation in the auction with } \\
\text { conditions (without conditions) }\end{array}$ & 14 & $2,128.94$ & $1,787.33$ & $+19.11 \%$ \\
\hline $\begin{array}{c}\text { through redemption by the buyer, } \\
\text { who is the only one to apply for } \\
\text { participation in the auction with a } \\
\text { reduction of the starting price by } \\
50 \%\end{array}$ & 9 & $5,513.05$ & $5,496.91$ & $+0.29 \%$ \\
\hline
\end{tabular}

Source: based on the [23]

The starting price of property in Ukraine is set by the privatization body, another state body or local self-government body (tender, auction commission established by these bodies), taking into account the results of property appraisal conducted in accordance with the Property 
Appraisal Methodology, which is the beginning of the sale of property in the ways established by the legislation, providing competition of buyers and change of the price during sale.

In general, the sale of small privatized properties on the basis of pricing at electronic auctions, which corresponds to the market approach of setting the price of state property, provides an increase in the appraised value of property (by $65.14 \%$ ). $70 \%$ of small privatized properties in Ukraine were sold at a higher price than the initial starting price. The total sales amounted to UAH 335,794.98 thousand compared to the initial total price of UAH $219,024.39$ thousand. Subsequent bidding resulted in a $49.75 \%$ reduction in the starting price for 28 properties. Thus, the method of step-by-step reduction of the starting price causes an underestimation of the value of state property. The initial reduction of the starting price by $50 \%$ provided an increase in the selling price by $39.56 \%$. At the same time, the price of the property remained understated in this case by $10.44 \%$. Conditional auctions are the most effective way to increase property prices. Lack of competition does not provide a significant increase in the value of property $(+19.11 \%$ and $+0.29 \%)$.

Large properties subject to privatization in Ukraine (PJSC "Odesa Portside Plant"; State Enterprise Electrotyazhmash Plant; JSC "United Mining and Chemical Company"; State Enterprise "Coal Company "Krasnolymanska") were sold with the involvement of entities engaged in providing services for preparation for privatization. Privatization did not take place, 1-2 stages of the Terms of Reference of State Property Sales Agreements were executed.

In the $1^{\text {st }}$ quarter of 2020 , the state privatization bodies of local self-government, which have been delegated the authority to privatize communal property, provided funds from the alienation of communal property and other revenues directly related to the privatization process in the amount of UAH 689.1 thousand, which are transferred to the relevant local budgets.

In the $1^{\text {st }}$ quarter of 2020 , the privatization bodies of Ukraine managed not only to maintain the level of efficiency of sales of properties, but also to increase sales through mechanisms of openness, clarity, transparency, fairness of privatization procedures, and to maintain the interest of buyers. In the $1^{\text {st }}$ quarter of 2020 , the properties were sold at higher prices than in the $1^{\text {st }}$ quarter of 2019 [23]. The Law of Ukraine No. 553-IX dated April 13, 2020 reduced the plan on the receipt of funds from privatization by the State Budget of Ukraine for 2020 [24] to UAH 500,000 million with a simultaneous significant reduction in the amount of expenditures on activities related to the privatization of state property to the level of actually paid works (from UAH 258.3 million to UAH 15.3 million, or a reduction of 16 times). For the $1^{\text {st }}$ quarter of 2020, the Fund received UAH 473.95 million from the privatization of property.

The mechanism of appraisal of state and communal property is based on the Methodology approved by Resolution of the Cabinet of Ministers of Ukraine No. 1891 dated December 10, 2003 (hereinafter referred to as "the Methodology") (as amended by [25]). According to the Methodology, independent appraisal is the determination by an appraisal entity (business entity) on the basis of an agreement for appraisal of a certain type of property, of the value of property, except appraisal value, in accordance with national appraisal standards and other regulations on independent appraisal.

Appraisal of properties subject to privatization is carried out in Ukraine in case of privatization by transformation of state and communal enterprises into joint-stock companies, in particular large and small properties; privatization of small properties to be redeemed and sold; in relation to properties that are being returned to state or communal ownership; property of state enterprises subject to reorganization by their transformation into joint stock companies; alienation of state (communal) property.

State privatization bodies (subjects of privatization are state privatization bodies; local councils, privatization bodies of territorial communities; buyers) enter into agreements for the 
appraisal of properties subject to privatization in cases provided by law. Privatization is seen as the alienation of state-owned property on a paid basis in favour of legal entities or individuals.

The goals of privatization of state and communal property includes attracting revenues to local budgets from sales in the short run, and from tax revenues in the long run. Other goals of privatization are to fight corruption, attract investment, improve the quality of property use and property management, and as a result - financial performance, modernization.

In Ukraine, the mechanism of property appraisal has been simplified by eliminating electronic platforms as intermediaries between citizens and the Unified Database of Appraisal Reports. This helped to eliminate systemic errors in the work of appraisers, fractional appraisals, and accelerate the process of privatizing state and communal property. In 2019, state privatization bodies, to which local governments have delegated their powers to privatize communal property in accordance with current legislation, provided funds from the alienation of communal property and other revenues directly related to the privatization process in the amount of UAH 5.860 million, which were transferred to the relevant local budgets.

Peculiarities of privatization and the mechanism of appraisal of properties subject to privatization in Ukraine correspond to the modern concept of asset management of municipalities, as they combine managerial and balance approaches to the appraisal of state property. The balance approach is manifested in the mass inventory and appraisal of various state and communal properties. The managerial approach is manifested in the financial analysis of state-owned enterprises (financial performance).

\section{DISCUSSIONS}

Today, in order to obtain a reliable appraisal of property, in addition to the cost approach as a traditional one, comparative and income approaches have become more widespread in relation to appraisal. This practice is typical of many Western European countries. Despite proving the effectiveness of privatization in developed countries [4], there was no methodology for management and appraisal of state property at the peak of privatization processes [3]. In the United Kingdom, the United States, and New Zealand, municipal property management practices have been characterized by limited use of managerial approach, strategic vision, and lack of professionalism of managers. The problem of finding additional sources of revenues of local budgets of developed countries has necessitated the privatization of municipal property [11]. The solution to this issue involved the transfer of property to the private sector, and was supported by large portfolios of municipal property, a developed legal framework and current property taxes [26]. A similar experience is observed in Ukraine today: the portfolio of property of local self-governments is being formed, inventory of property and mass appraisal of communal property is ongoing. These processes are supported by law and regulated by maintaining open appraisal registers from a single database of appraisal reports.

Ukraine, as developed countries (Sweden), carries out mass appraisal of state property [27] during privatization. Appraisal includes approval of the methodology of property valuation, methodology of determining the authorized capital during reorganization, development of software for automation of valuation processes at the local level, dissemination of standardized form of data collection as a basis for appraisal, training for entities engaged in appraisal [28]. Similar experience is implemented in transition economies (Georgia, Ukraine), which indicates the solution of the problems of underappraisal or overappraisal of state property, the problem of unprofessional appraisers [11]. These problems determine the level of protection of local and foreign investors in the process of privatization and investment, determine the effectiveness of receiving revenues by the local budgets.

Transition economies face problems of appraisal of municipal property (Georgia, Latvia) [27]. Determining market value is a particularly important issue in a competitive environment 
[29]. In transition economies, the inaccuracy and inconsistency of information can exacerbate this problem. The inaccuracy of information on value in transition economies is due, among other things, to undeveloped financial markets. The problem of inaccuracy of information is solved by a transparent mechanism for regulating auctions, which set the market price of state property.

Accounting and methods of accounting of state property are characterized by international conceptual differences, which provide for different methods of appraisal of property during privatization. The introduction of an effective state policy of state property appraisal, taking into account the experience of privatization of developed countries, is becoming an urgent global-scale need [16]. This problem exacerbates during periods of financial crisis, when the state budget deficit increases sharply and there are risks of significant underappraisal of state property. Even in developed countries (USA, Canada), there is no market valuation of state property for accounting purposes [17]. The crisis of public finances is affecting the assets of municipalities. The example of the EU countries of 2008-2009 proves increasing risks related to state property: the risk of underestimation of value and risks of efficiency in the long run. As a result of increased risks, EU countries accelerated the sale of state property at a reduced price and used the proceeds from the sale to eliminate the effects of the crisis [18]. An effective policy of state property appraisal should provide for the recognition of economic appraisal of property, administrative responsibility for the appraisal, involvement of professionals to conduct appraisal, development of a conceptually sound methodology [17].

\section{CONCLUSIONS}

The study proves the effectiveness and crucial role of state and communal property appraisal in the effectiveness of property privatization and ensuring fiscal efficiency. A review of practices of state property appraisal proves the mass appraisal and the importance of independent appraisal institutions. In the conditions of an underdeveloped financial market, which causes the absence of the possibility of public offering of shares of state-owned enterprises, a strong and independent appraisal institution ensures competition and the implementation of a market approach to appraisal. Recent trends in the appraisal of state-owned assets indicate the importance of ensuring the independence of the appraisal institution by: reforming state regulators; political stability; fighting corruption and political ties. Another important feature of ensuring the correct property appraisal: the creation of a competitive environment and market conditions for pricing. While in developed countries these prerequisites are provided by a developed capital market and the possibility of public offering of shares, in transition economies these prerequisites can be provided by the establishment of a transparent electronic sales mechanism. Therefore, appraisal of properties subject to privatization in Ukraine is carried out in accordance with international standards and the principles of transparency, openness of procedures based on electronic auctions. During the period 2018-2020, this was the reason for the increase in the price of sales of state property, as well as for an acceleration of privatization and increased revenues to local budgets. Given the identified features of appraisal procedures, as an important stage of privatization, we can confirm Hypothesis 1 on ensuring a higher level of revenues to local budgets in the short term through transparent property appraisal mechanisms.

Thus, appraisal of state property provides fiscal efficiency through a competitive marketbased sales mechanism. Given the existing limitations on the data of appraisal of state and communal property, the limitation of data on the amount of revenues to local budgets from privatization, we cannot confirm Hypothesis 2. At present, it is not possible to determine the long-term effects of the appraisal of properties of territorial communities of Ukraine subject to privatization as a source of attracting additional revenues from tax payments. This is an 
opportunity to conduct further research on the economic, fiscal effects of appraisal of state and municipal property.

\section{REFERENCES}

[1] Aggarwal, R. and Harper, J. T. Privatization and Business Valuation in Transition Economies. In L. L. Jacque and P. M. Vaaler (eds.), Financial Innovations and the Welfare of Nations. Boston, MA: Springer, 2001, pp 175-196.

[2] Roje, G. and Redmayne, N. On the management and financial reporting for state assets - a comparative analysis between Croatia and New Zealand. Public Money \& Management, 2020. https://doi.org/10.1080/09540962.2020.1723261

[3] Kaganova, O. and Nayyar-Stone, R. Municipal real property asset management: An overview of world experience, trends and financial implications. Journal of Real Estate Portfolio Management, 6(4), 2000, pp. 307-326.

[4] Estrin, S. and Pelletier, A. Privatization in developing countries: What are the lessons of recent experience? The World Bank Research Observer, 33(1), 2018, pp. 65-102. https://doi.org/10.1093/wbro/lkx007

[5] Megginson, W. L. and Netter, J. M. From state to market: A survey of empirical studies on privatization. Journal of Economic Literature, 39(2), 2001), pp. 321-389.

[6] Peña-Miguel, N. and Cuadrado-Ballesteros, B. The role of governance in privatisation reforms: A European analysis. Scottish Journal of Political Economy, 65(1), 2018, pp. 479-500. https://doi.org/10.1111/sjpe.12192

[7] Kaganova, O. and Amoils J. A. Central government property asset management: a review of international changes, Journal of Corporate Real Estate, 2020. https://doi.org/10.1108/JCRE09-2019-0038

[8] Kawasaki, A. and Naito, T. (2019). Partial Privatization under asymmetric multi-market competition. Review of Urban \& Regional Development Studies, 31(1-2), 2019, pp. 60-76. https://doi.org/10.1111/rurd.12098

[9] Burkhardt, B. C. The politics of correctional privatization in the United States. Criminology \& Public Policy, 18(2), 2019, pp. 401-418. https://doi.org/10.1111/1745-9133.12431

[10] Hardell, S., Johansson, I. and Öun S. I. Welfare service privatization and opinions about service quality: The role of political ideology among local politicians and the public. Social Policy Administration, 54(1), 2019, pp. 45-59. https://doi.org/10.1111/spol.12509

[11] Farrell, H. Privatization as State Transformation. Privatization. In J. Knight and M. Schwartzberg (eds.), Privatization: NOMOS LX. New York: NYU Press, 2018, pp. 171-199. https://doi.org/10.18574/nyu/9781479842933.003.0008

[12] Somé, H. Y., Cano-Kollmann, M., Mudambi, R. and Cosset, J.-C. The effect of privatization on the characteristics of innovation. Financial Management, 2020. https://doi.org/10.1111/fima.12311

[13] Reinsberg, B., Stubbs, T., Kentikelenis, A. and King, L. (2019). Bad governance: How privatization increases corruption in the developing world. Regulation and governance, 2019. https://doi.org/10.1111/rego.12265

[14] Bjorvatn, K. and Eckel, C. Strategic privatization in developing countries. Review of Development Economics, 15(3), 2011, pp. 522-534. https://doi.org/10.1111/j.14679361.2011.00624.x

[15] De Castro, J. O. and Uhlenbruck, N. Comparing privatization characteristics in former communist, developing, and developed countries. In E. Kaynak, A. Lewis and A. A Ullmann (eds.), Privatization and Entrepreneurship. New York: Routledge, 2018, pp.89-102. https://doi.org/10.4324/9780203714584-7

[16] Estrin, S., Hanousek, J., Kočenda, E. and Svejnar, J. Effects of privatization and ownership in transition economies. Journal of Economic Literature, 47(3), 2009, pp. 699-728. https://doi.org/10.1257/jel.47.3.699 
Appraisal of Property of Local Self-Government Bodies: a Role in the Effectiveness of Property Privatization as a Source of Increasing Revenues of Local Budgets

[17] Kaganova, O. Valuation and pricing of government land and property: A tip of a growing iceberg. Real estate issues, 37(1), 2012, pp. 9-16.

[18] Kaganova, O. Government property assets in the wake of the dual crisis in public finance and real estate. Real estate issues, 35(3), 2011, pp. 31-41.

[19] Privatization barometer. http://www.privatizationbarometer.com/index.php

[20] Louzek, M. Czech privatisation 25 years later. The World Economy, 42(3), 2018, pp. 975-986. https://doi.org/10.1111/twec.12714

[21] Analytical information on the work of the State Property Fund of Ukraine and the course of privatization of state property in the first quarter of 2020. State Property Fund of Ukraine, 2020. http://www.spfu.gov.ua/ua/documents/press-list/spf-reports/14825.html

[22] Information on state-owned objects. Information on the formation and maintenance of the Unified Register of State Property as of 01.01.2020. State Property Fund of Ukraine, 2020. http://www.spfu.gov.ua/ua/content/spf-stateproperty-info.html

[23] State Property Fund of Ukraine. Report on the work of the State Property Fund of Ukraine and the progress of privatization of state property in 2019. http://www.spfu.gov.ua/userfiles/pdf/zvit19_14800.pdf

[24] Law of Ukraine No. 553-IX: On Amendments to the Law of Ukraine "On the State Budget of Ukraine for 2020". Legislation of Ukraine, 2020. https://zakon.rada.gov.ua/laws/show/553-20

[25] Resolution of the Cabinet of Ministers of Ukraine No. 1033: On Amendments to the Methodology of Property Valuation. State Property Fund of Ukraine, 2015. http://www.spfu.gov.ua/ua/documents/4081.html

[26] Auwalin, I. Privatization in developing countries: A promising development strategy? KnE Social Sciences, 3(13), 2019, pp. 1266-1269.

[27] Kalandadze, L. The issues of real estate valuation in the process of privatization. Baltic Journal of Real Estate Economics and Construction Management, 5, 2017, pp. 201-208. https://doi.org/10.1515/bjreecm-2017-0015

[28] Suleiman, E. N. and Waterbury, J. Introduction: Analyzing privatization in industrial and developing countries. In the Political Economy of Public Sector Reform and Privatization. New York: Routledge, 2019, pp. 1-21. https://doi.org/10.4324/9780429313707-1

[29] Foldvary, F. E. Government Ownership and Privatization. In M. S. Kimenyi and J. M. Mbaku (eds.), Institutions and Collective Choice in Developing Countries. London: Routledge, 2019, pp. 291-314. https://doi.org/10.4324/9780429441523-12

[30] A.G. Gaddamwar and P. R. Rajput, A Review on Privatization in Education is the Boon for Percentages of Educated and Bane for Quality, Unemployment, International Journal of Mechanical Engineering and Technology (IJMET), Volume 4, Issue 4, July - August (2013), pp. 373-376.

[31] R. Govindaraj and P. Sabapathy, The Origin and Growth of Thanjavur Local Self Government, Journal of Management, 5(6), 2018, pp. 151-156. 